\title{
Mapping Agricultural Frozen Soil on the Watershed Scale Using Remote Sensing Data
}

\author{
Jalal Khaldoune, ${ }^{1}$ Eric Van Bochove, ${ }^{2}$ Monique Bernier, ${ }^{1}$ and Michel C. Nolin² \\ ${ }^{1}$ Institut National de la Recherche Scientifique-Eau, Terre et Environnement (INRS-ETE), 490 rue de la Couronne, \\ QC, Canada G1K $9 A 9$ \\ ${ }^{2}$ Agriculture and Agri-Food Canada, Soils and Crops Research and Development Centre, 2560 Hochelaga Boulevard, \\ QC, Canada G1V $2 J 3$
}

Correspondence should be addressed to Jalal Khaldoune, khaldoune@yahoo.com

Received 6 December 2010; Revised 21 February 2011; Accepted 20 March 2011

Academic Editor: Mehrez Zribi

Copyright (๑) 2011 Jalal Khaldoune et al. This is an open access article distributed under the Creative Commons Attribution License, which permits unrestricted use, distribution, and reproduction in any medium, provided the original work is properly cited.

\begin{abstract}
This paper presents an empirical model for classifying frozen/unfrozen soils in the entire Bras d'Henri River watershed $\left(167 \mathrm{~km}^{2}\right)$ near Quebec City (Quebec, Canada). It was developed to produce frozen soil maps under snow cover using RADARSAT-1 fine mode images and in situ data during three winters. Twelve RADARSAT-1 images were analyzed from fall 2003 to spring 2006 to discern the intra- and interannual variability of frozen soil characteristics. Regression models were developed for each soil group (parent material-drainage-soil type) and land cover to establish a threshold for frozen soil from the backscattering coefficients (HH polarization). Tilled fields showed higher backscattering signal $(+3 \mathrm{~dB})$ than the untilled fields. The overall classification accuracy was $87 \%$ for frozen soils and $94 \%$ for unfrozen soils. With respect to land use, that is, tilled versus untilled fields, an overall accuracy of $89 \%$ was obtained for the tilled fields and $92 \%$ for the untilled fields. Results show that this new mapping approach using RADARSAT-1 images can provide estimates of surface soil status (frozen/unfrozen) at the watershed scale in agricultural areas.
\end{abstract}

\section{Introduction}

Soil freezing is a critical attribute for sustaining agricultural production. It has a major impact on soil water erosion at snowmelt [1,2] and causes winterkill of perennial crops [3]. Soil water erosion and surface runoff are major sources for transporting water from agricultural land to streams. Soil sediments adversely affect surface water quality and often carry phosphorus, ammonia, pathogens, trace elements, and other contaminants from agricultural sources [4]. In Eastern Canada, the extent of this diffuse pollution is exacerbated when significant snowmelt runoff occurs on bare and erodible frozen agricultural soils located on sloping fields [5]. Environmental conditions in spring can significantly affect water transport. Early snow accumulation on wet soils may result in more unfrozen soils [6], or shallowly frozen soils, that allow higher infiltration of water at spring melt which consequently decreases runoff $[7,8]$. Late snow accumulation on relatively dry soils with cold air temperatures will allow frost to penetrate deeper below the soil surface. Soils frozen below a 15-cm depth can impede water infiltration [9] and generate a greater risk of erosion and snowmelt runoff at spring thaw. Despite the environmental impacts of frozen soils, soil temperature is poorly documented in Canada; agricultural lands are not systematically monitored by meteorological stations. Clearly, soil temperature is a critical attribute needed in meteorological databases to predict frozen soil status, to analyze environmental impacts of agricultural production, and to develop best management practices.

Remote sensing offers promising techniques for monitoring near-surface frozen and unfrozen soil status on broad geographical scales [10]. In the past, passive microwave remote sensing was explored. [11] used special sensor microwave/imager (SSM/I) data to detect soil freeze and thaw states over snow-free land. Using data from the Nimbus 7 scanning multichannel microwave radiometer (SMMR) for brightness temperature, [12] shows that frozen ground can be discerned from unfrozen ground for pasture soils. Both sensors provide poor spatial resolution $(10-50 \mathrm{~km})$, however, which restricts their use to only very large areas. 
Satellite measurements of thermal radiation (3-14 um) have been widely used to determine soil surface temperature [1315], but these thermal sensors cannot provide data under cloudy conditions. In addition, since much of the frozen soil in Eastern Canada is covered by snow, the need to determine frozen and unfrozen status under snow cover conditions is obvious. Unlike the thermal infrared or passive microwave sensors, synthetic aperture radar (SAR) systems can potentially provide information concerning soil freezing dynamics under snow cover at high resolution regardless of cloud cover and time of day and night. The radar signal predominantly depends on the dielectric constant of soil which itself is directly related to the water and ice content, respectively [16]. RADARSAT-1 is a high SAR spatial resolution $(9 \mathrm{~m})$ sensor operating in the C-band $(5.3 \mathrm{GHz})$ which also covers the watershed level when the soil is dry and the snow cover is virtually transparent [17]. According to [18], only $5 \%$ of the transmitted signal is diffused into the snow cover to a $30-\mathrm{cm}$ depth, which corresponds to a decrease of approximately $0.2 \mathrm{~dB}$ in the backscattered signal. Some specific studies on radar conclude that results obtained using SAR sensors may provide useful information on ground moisture and near-surface frozen and unfrozen bare soil status [17, 19-21]. However, imaging frozen soil on the watershed scale using RADARSAT-1 remains unexplored.

Active sensors discern frozen soil by detecting variations in liquid soil water content. These variations are related to soil dielectric constant values [22-26]. The average dielectric constant value of dry soil is about 2-3, while that of liquid water is 80 [27]. The dielectric contrast between soil and air is low when the soil is dry $(\sim 3)$, because less energy is diffused at its surface [23]. The soil dielectric constant increases proportionally with volumetric liquid water content, which allows the radar sensor to discern dry soil from wet soil. Under critical winter conditions, a greater proportion of soil water freezes which leads to a significant decrease of the average soil dielectric constant; frozen water has a dielectric constant of ice (3.2) which is similar to that of dry soil [2830]. The opposite phenomenon occurs during spring thaw when the ice within soil melts, which results in the radar cross-section increasing by several dB [31-34]. Reflections occur at interfaces that are related to abrupt changes in dielectric permittivity, for example, at the frozen/unfrozen ground interface. Hence, radar can be employed to spatially distinguish between dry and wet areas as well as between frozen and unfrozen soil.

Soil properties (i.e., structure, texture, and drainage) influence the soil water content and consequently its freezing dynamics. Each soil has its specific latent heat flux that increases with water content and which requires more heat loss to freeze $[35,36]$. Mineral soils freeze more quickly and more deeply than organic soils because of their lesser capacity to store water [37]. The same relation exists between sandy and clay soils.

Soil moisture is not the only attribute that affects the radar backscattering signal; vegetative cover and soil surface roughness also have an effect $[38,39]$. Many studies have evaluated the effects of surface roughness on the radar signal [23, 40-43]. For example [44] report that surface roughness effects are more important with greater soil moisture content and [45] suggest that the effect of roughness may be considered as being constant within an agricultural area for some cases. Although surface roughness indices are affected by many factors, such as crop, soil management, crop residues, and field orientation, winter conditions preceding the spring melt in eastern Canada present more stable indices due to the lack of agricultural activity compared with other seasons. Consequently, these more stable surface conditions are favourable to successive radar image acquisitions during winter.

The objective of this study was to classify the nearsurface agricultural soils as being frozen or unfrozen relative to changes in the RADARSAT-1 backscattering signal under dry snow cover. A linear regression model between the soil surface temperature and the radar backscattering signal was developed to predict surface temperatures, to classify RADARSAT-1 images, and to derive frozen soil maps on the watershed scale. The regression model was assessed from interactions between in situ ground measurements and remote sensing data acquired from 12 representative agricultural fields within the Bras d'Henri watershed $\left(167 \mathrm{~km}^{2}\right)$ during winters from 2003 to 2006.

\section{Material and Methods}

2.1. Study Area. The Bras d'Henri study site $\left(167 \mathrm{~km}^{2}\right)$ is a subwatershed of the Beaurivage and Chaudière basins, located south of Quebec City and the Saint-Lawrence River (Figure 1). Soil classification and attributes of the studied area are described in Table 1; they belong mainly to the podzol $(47.6 \%)$, gleysol $(30.5 \%)$, organic $(11.1 \%)$, and brunisol $(5.7 \%)$ order. The drainage classes for the mineral and organic soils ranged from being well (21.9\%), moderately $(16.6 \%)$, imperfectly $(17.2 \%)$, poorly $(26.5 \%)$, and very poorly drained (15.2\%). The surface texture ranged from sandy loam to loam, while the family particle-size classes include soils with sandy, coarse-loamy, fine-silty, and sandy-skeletal attributes (Table 1). The organic soils identified in the watershed consist of highly decomposed humic layers [46]. Soils were generally developed over fluvial and fluviolacustrine deposits [47].

The cold temperate climate is characterized by a severe winter with a moderate and subhumid summer. Mean annual temperature is $4.5^{\circ} \mathrm{C}-6.6^{\circ} \mathrm{C}$ with an average annual precipitation of $1126 \mathrm{~mm}$ and a normal snowfall of $320 \mathrm{~cm}$. Early snow accumulation may insulate the soil from freezing depending on local conditions. The freezing period starts around mid-November and lasts until mid-April. The studied area has the most intensive livestock production of the watershed, which generates a surplus of nutrients. Slope of the fields in the studied area ranges from $0 \%$ to $9 \%$, which increases the risk of surface runoff, soil water erosion, and the transport of sediments, phosphorus, and other contaminants (pathogens, herbicides, and trace elements) from agricultural land to streams [6].

2.2. In Situ Data Measurements. Field observations, including soil temperature, soil moisture content, and snowpack 


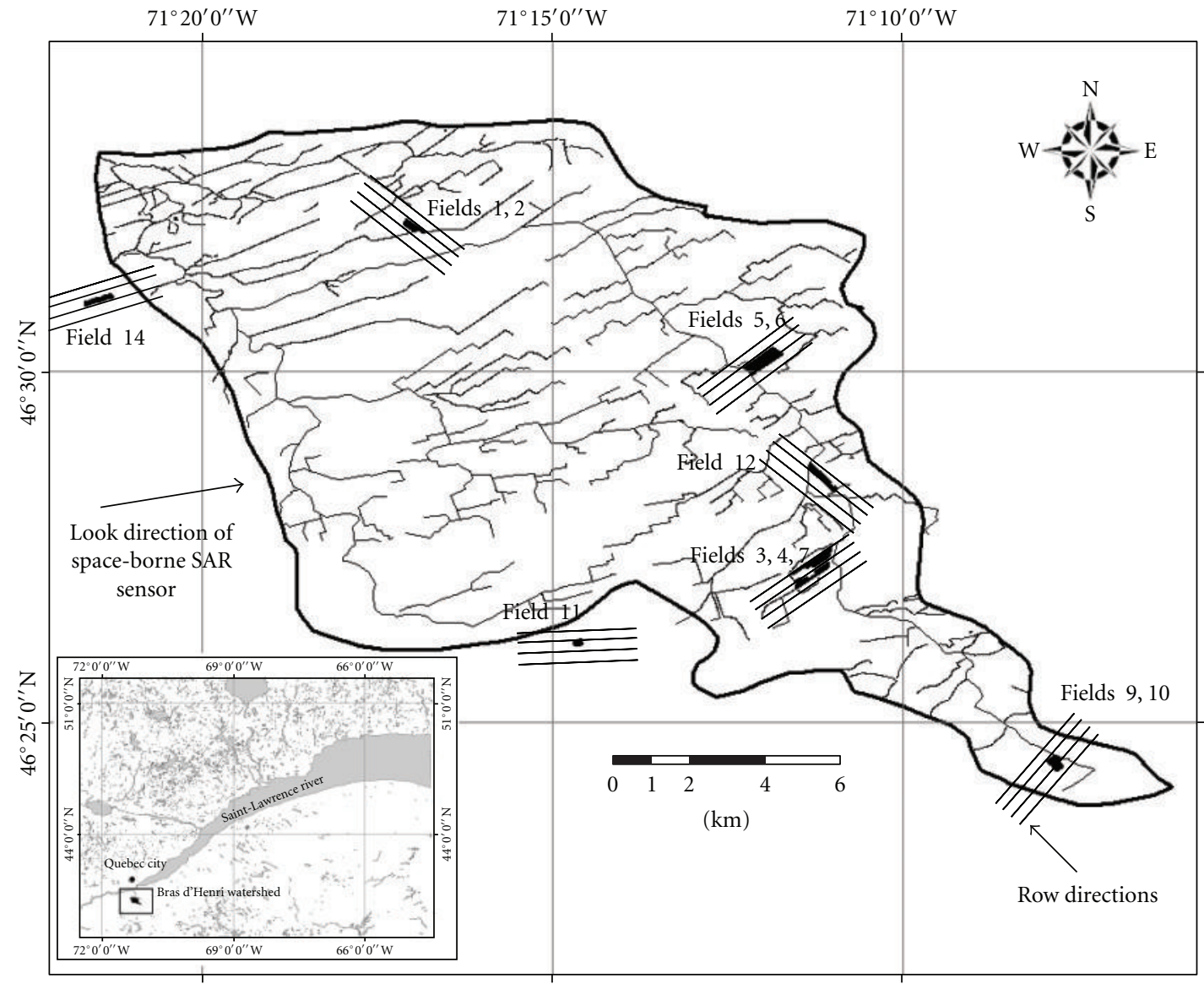

FIgURE 1: Location of the 12 study fields within the Bras d'Henri watershed.

characteristics, were measured in 12 fields and are described in Tables 1 and 2. Field data for analysis were collected simultaneously with satellite acquisitions. All soil attributes repeatedly measured on the same field were averaged. Because the influence of soil moisture on radar signals under dense vegetation (forest) is weak, these areas were eliminated from the radar image analysis. Therefore, soil moisture measurements were considered for only bare soil and sparsely dispersed vegetation (Figure 2).

The soil temperature was measured at six different depths $(5,10,15,35$, and $50 \mathrm{~cm}$ below the soil surface) using copperconstantan thermocouples (Type T, Omega, Standford, Connecticut). Thermocouples were installed during the fall and their locations were georeferenced. Air temperature was measured with a portable thermometer. Each field was sampled over five temperature profiles, with the minimum distance between profiles being $45 \mathrm{~m}$. A digital elevation model (DEM) and detailed soil maps were used to determine five representative locations within each field.

A time domain reflectometer (TDR) probe was also installed at $5 \mathrm{~cm}$ below the soil surface for dielectric constant measurement [48]. Soil moisture was measured using TDR technology. An automatic meteorological station was mounted on a representative field within the monitoring network. Hourly average air temperature, snow height, and wind direction were recorded. The snow was considered to be dry when the air temperature was below $0^{\circ} \mathrm{C}$ on the night preceding a SAR image acquisition.

The effect of soil type and land use (tilled versus untilled) on the radar signal was evaluated relative to the soil series classification according to [49]. The resultant soil classification was based on soil properties, with emphasis on various soil drainage indicators. The Beaurivage sandy loam soils belong to the moderate-to-rapid soil permeability class $\left(5-15 \mathrm{~cm} \mathrm{hr}^{-1}\right)$, whereas the other soils have moderateto-slow permeability $\left(0.5-1.5 \mathrm{~cm} \mathrm{hr}^{-1}\right)$. Since the measurements taken by synthetic aperture radar (SAR) instruments are sensitive to soil moisture, it is hypothesized that the drainage class of each soil type studied within the watershed has an impact on the radar backscattering signal. Moreover, the soil classification at the series level is principally based on soil drainage and soil water holding capacity, two attributes highly related to soil moisture content and soil dielectric constant.

2.3. SAR Data Acquisitions. Twelve RADARSAT-1 SAR images were acquired during three winter seasons, from fall 2003 to spring 2006. Images were centered on $46^{\circ} 29^{\prime} \mathrm{N}$ and $71^{\circ} 14^{\prime} \mathrm{W}$. RADARSAT- 1 was scheduled to acquire C band (frequency $5.3 \mathrm{GHz}$ corresponding to a wavelength of 


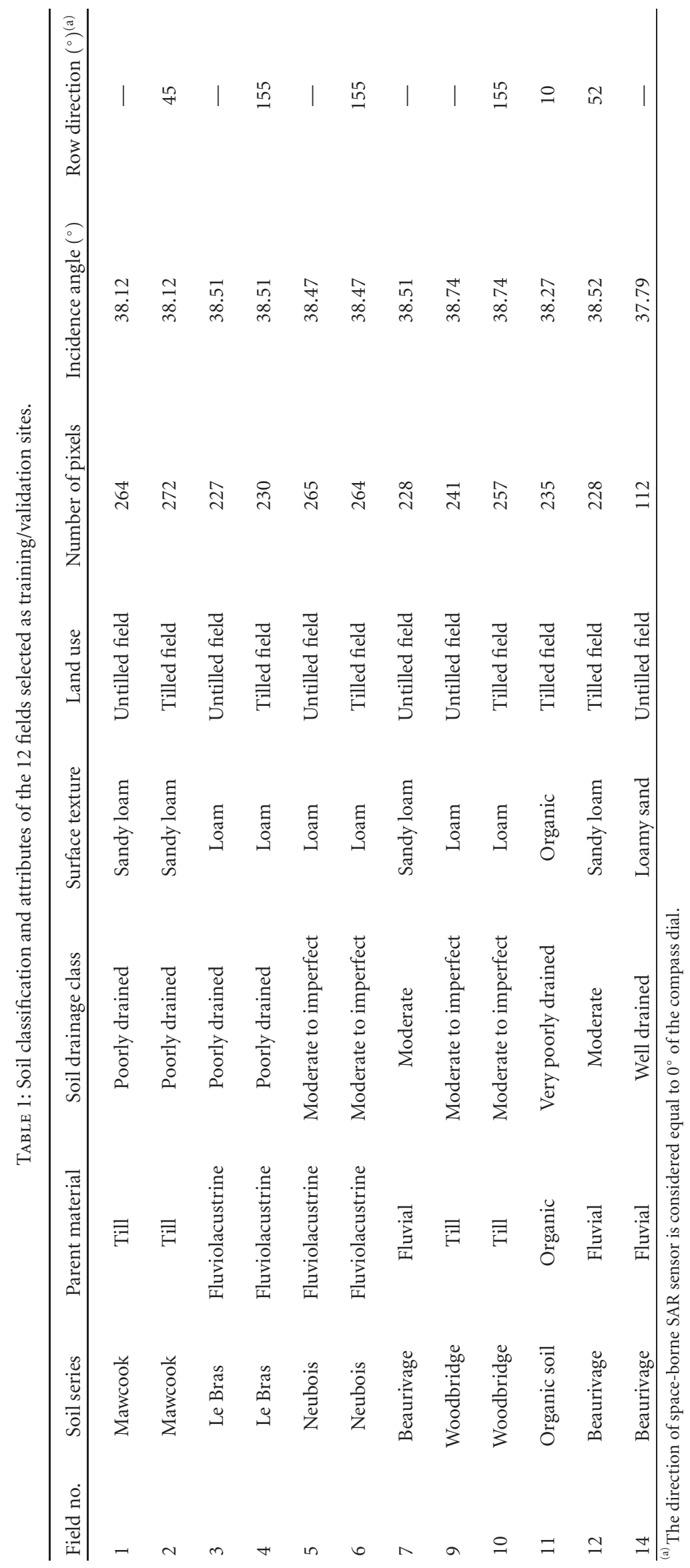




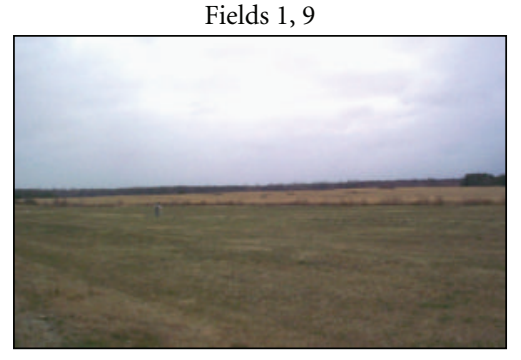

(a)

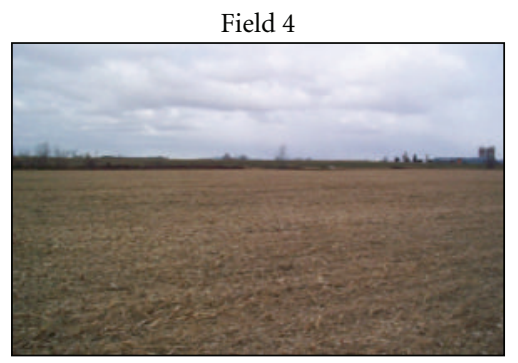

(d)

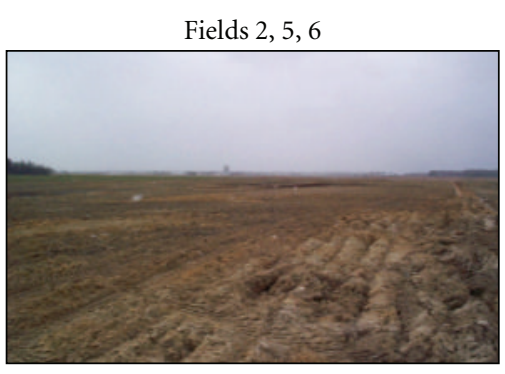

(b)

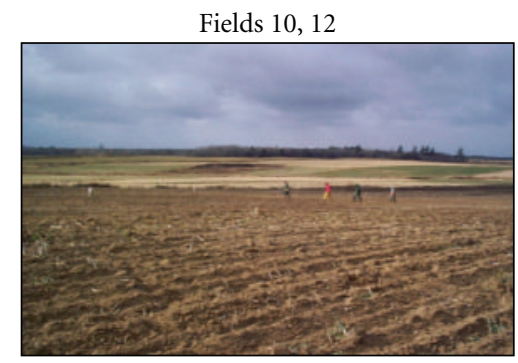

(e)

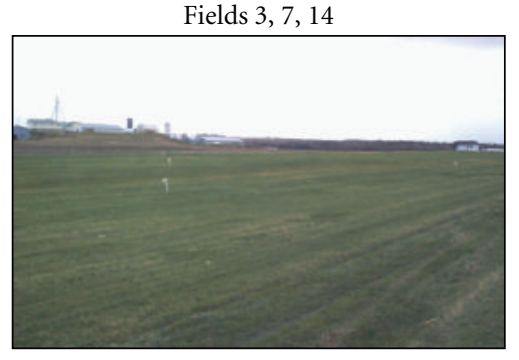

(c)

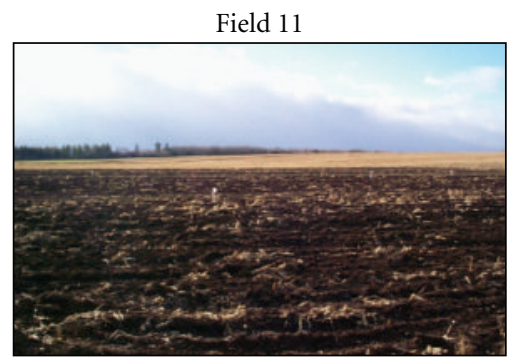

(f)

FIgURE 2: Photographs showing the types of land cover considered in this study: untilled fields $(1,3,7,9$, and 14), tilled fields $(2,4,5,6,10$, 11, and 12).

TABLE 2: Soil textures and attributes of the 12 fields selected as training/validation sites.

\begin{tabular}{|c|c|c|c|c|c|c|}
\hline Field no. & Organic (\%) & Sand $(\%)$ & Silt (\%) & Clay (\%) & Texture & Altitude $(\mathrm{m})$ \\
\hline 1 & 4.31 & 56.7 & 30.5 & 12.8 & Sandy loam & 139.36 \\
\hline 2 & 3.50 & 55.0 & 31.6 & 13.5 & Sandy loam & 140.03 \\
\hline 3 & 3.35 & 47.9 & 38.7 & 13.4 & Loam & 180.37 \\
\hline 4 & 5.11 & 52.3 & 34.2 & 13.5 & Sandy loam & 178.46 \\
\hline 5 & 4.25 & 47.4 & 42.0 & 10.7 & Loam & 158.06 \\
\hline 6 & 2.68 & 44.2 & 43.2 & 12.5 & Loam & 157.31 \\
\hline 7 & 3.75 & 47.6 & 45.0 & 7.4 & Loam & 184.38 \\
\hline 9 & 3.05 & 52.8 & 39.7 & 7.4 & Sandy loam & 282.81 \\
\hline 10 & 3.75 & 41.2 & 45.4 & 13.3 & Loam & 292.37 \\
\hline 11 & 42.06 & - & - & - & Organic & 173.19 \\
\hline 12 & 3.40 & 69.4 & 25.4 & 5.3 & Sandy loam & 173.67 \\
\hline 14 & 1.82 & 79.5 & 17.1 & 3.4 & Loamy sand & 131.88 \\
\hline
\end{tabular}

$5.6 \mathrm{~cm}$ ) polarization $\mathrm{HH}$ SAR images on ascending orbit in fine mode $(\mathrm{F} 1 \mathrm{~F})$, which corresponded to incidence angles varying from $36.9^{\circ}$ to $40.1^{\circ}$. It has been shown that low incidence angles $\left(20^{\circ}-30^{\circ}\right)$ reduce the influence of soil surface roughness [23, 43, 50-52]. However, for this study, despite its high incidence angle, the fine beam mode of RADARSAT-1 was selected for its fine spatial resolution $(9 \mathrm{~m}$ $\times 9 \mathrm{~m}$ ) that offers an advantage for mapping frozen soils at the field scale. Moreover, the roughness has to remain unchanged during the acquisition of all images.

The OrthoEngine program of PCI Geomatica (V9.1.5) was used to geometrically correct each RADARSAT-1 image registered with intensity (power) backscatter values in 32bit real channel. The mathematical modelling was based on a photogrammetry method [53], and the output images were resampled to a pixel spacing of $9 \mathrm{~m}$ using the bilinear technique.

A mask was applied to all fields allowing the extraction of the mean, the minimum, the maximum, and the standard deviation from image intensity values. Radar data intensity values were converted to backscattering coefficients $(\mathrm{dB})$ using (1) and (2) to allow a quantitative comparison of frozen and unfrozen soil values within the scene

$$
\mathrm{dB}=10 \times \log _{10}(\text { Intensity }),
$$

where the intensity (power) is given by

$$
\text { Intensity }=\sigma_{i j}=\frac{D N * D N+A_{0}}{A_{j}} * \sin \left(I_{i j}\right) \text {, }
$$


TABLE 3: Description of the RADARSAT-1 images acquired over the Bras d'Henri watershed during the three winter seasons (2003-2004 to 2005-2006) and the reasons for the use of only 12 radar images in this study.

\begin{tabular}{|c|c|c|c|}
\hline Winter season & Dates of RADARSAT-1 image acquisitions & Use (yes/no) & Reason \\
\hline \multirow{8}{*}{ First } & 08 November 2003 & Yes & Dry snow \\
\hline & 02 December 2003 & Yes & Dry snow \\
\hline & 26 December 2003 & No & Wet snow surface coinciding with the \\
\hline & & & RADARSAT- 1 overpass \\
\hline & 19 January 2004 & Yes & Dry snow \\
\hline & 25 January 2004 & No & Wet snow surface coinciding with the \\
\hline & & & RADARSAT- 1 overpass \\
\hline & 29 February 2004 & Yes & Dry snow \\
\hline \multirow{10}{*}{ Second } & 02 November 2004 & Yes & Dry snow \\
\hline & 06 December 2004 & No & Acquisition failures due to the \\
\hline & & & conflicts with other users. \\
\hline & 10 January 2005 & No & Acquisition failures due to the \\
\hline & & & conflicts with other users. \\
\hline & 13 January 2005 & Yes & Dry snow \\
\hline & 06 February 2005 & No & Wet snow surface coinciding with the \\
\hline & & & RADARSAT- 1 overpass \\
\hline & 14 February 2005 & No & Acquisition failures due to the \\
\hline & & & conflicts with other users. \\
\hline \multirow{6}{*}{ Third } & 08 January 2006 & Yes & Dry snow \\
\hline & 01 February 2006 & Yes & Dry snow \\
\hline & 25 February 2006 & Yes & Dry snow \\
\hline & 21 March 2006 & Yes & Dry snow \\
\hline & 14 April 2006 & Yes & Dry snow \\
\hline & 08 May 2006 & Yes & Dry snow \\
\hline
\end{tabular}

where $\sigma_{i j}$ is the output backscattering coefficient for line $i$, pixel $j, D N$ is the input image value for line $i$, pixel $j, A_{0}$ is the gain offset from the first member of SAR scaling offset segment $\left(A_{0} \mathrm{SEG}\right), A_{j}$ is the expanded gain scaling tabular value for pixel $j$, and $I_{i j}$ is the local incidence angle.

In order to map frozen soils on the watershed scale, only images that presented dry snow cover conditions were retained (Table 3 ). Images taken wherever air temperature was above the freezing point were discarded due to a wet snow cover. The backscattering behavior changes for a wet snow cover, resulting in low values of the backscattering coefficient for incident angle $\theta>20^{\circ}$. The lower values under wet snow conditions are due to increased attenuation by the snow cover when its surface is relatively smooth $[54,55]$. The RADARSAT-1 images were filtered to smooth and wipe off the noise, reducing the speckle effect. To achieve this task, a 5 $\times 5$ Gaussian filter was applied to all 12 RADARSAT- 1 images [56].

The three assumptions underlying the linear regression model were verified prior to using the data: (1) residuals were normally distributed, (2) the residual mean was equal to zero, and (3) residuals were not autocorrelated

\section{Results and Discussion}

The effects of land use, air temperature, and snow cover thickness on frost depth were studied for the 12 fields selected for monitoring and validation. In the following sections, the backscattering coefficients of the images are related to ground data measurements (snow cover thickness, soil moisture, and frozen soil depth) taking soil type into account. These relationships were developed for untilled and tilled fields (Figure 2), during two winters (November 2003 to April 2004 and November 2004 to April 2005) and then applied to a third winter (January to April 2006).

3.1. Snow Cover and Soil Temperature. The weather records for the 2004, 2005, and 2006 winter seasons are presented in Figure 3. In general, the average daily temperature drops below $0^{\circ} \mathrm{C}$ on November and the snowpack initiates on December. However, the average air temperature does not stay continuously below $0^{\circ} \mathrm{C}$ during the winter Figure 3(a). The minimum recorded air temperature was $-27.5^{\circ} \mathrm{C}$ on January $25,2004,-27^{\circ} \mathrm{C}$ on January 13,2005 , and $-17^{\circ} \mathrm{C}$ on February 26, 2006. The daily average snow accumulation 


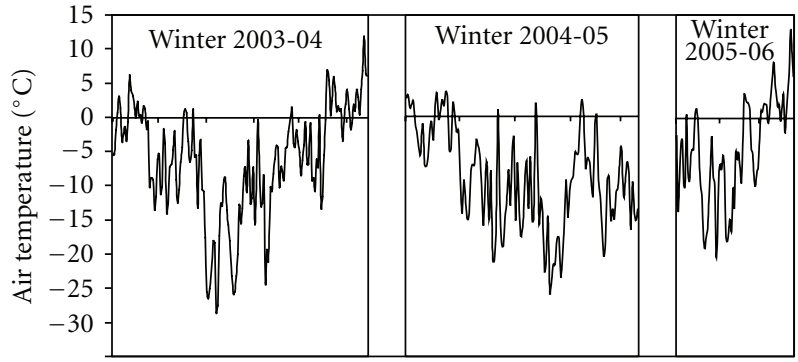

(a)

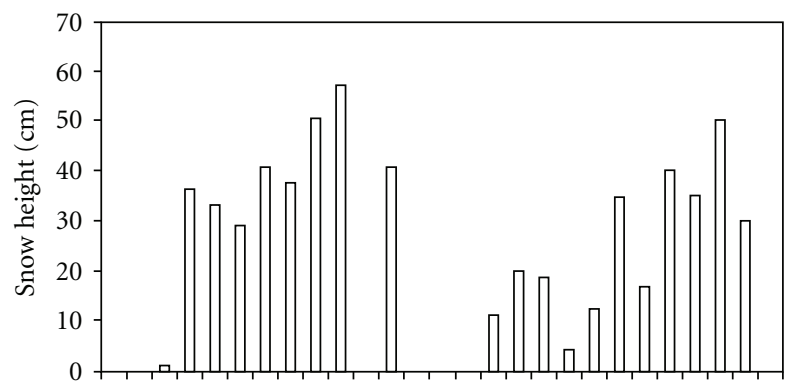

(b)

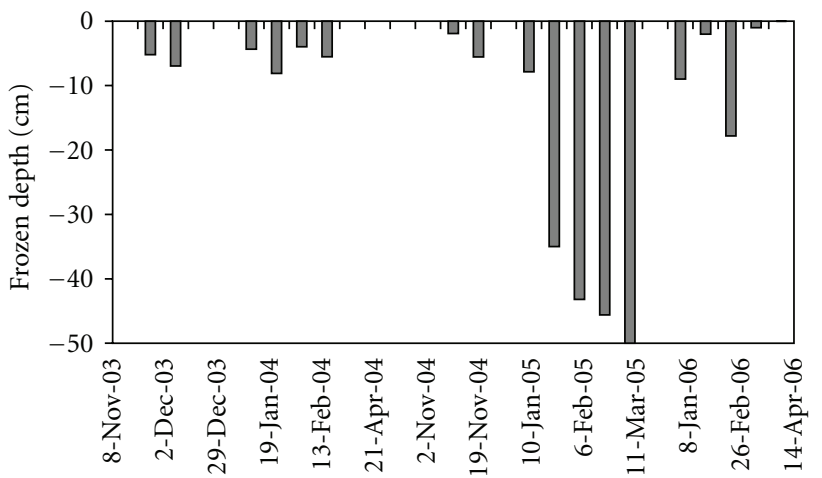

(c)

FIgURE 3: Temporal variation for: (a) air temperature, (b) snow height, and (c) frozen depth $(0-50 \mathrm{~cm}$ depth).

reached its maximum in different months from year to year (Figure 3(b)).

During the winter of 2004, it was observed that when the air temperature dropped below $-10^{\circ} \mathrm{C}$, the near-surface soil layers froze. The first soil type to freeze was the Neubois loam (fields 5 and 6), while the organic soil (field 11) was the last (results not shown). Snow accumulation began on December 22 with a snow-cover thickness of about $38 \mathrm{~cm}$. The period of freezing was preceded by snow accumulation which reached a maximum of $66 \mathrm{~cm}$ in field 2 on February 29, 2004. Because field 2 was tilled, the frost penetrated deeper in the soil $(30 \mathrm{~cm})$ than in the untilled field $1(11 \mathrm{~cm})$, which was covered with hay. The winter of 2005 had less precipitation and less snow cover $(20 \mathrm{~cm})$, while the air temperature was similar to the winter of 2004. This condition accelerated the frost penetration into the ground, which reached a depth of up to $50 \mathrm{~cm}$. The variation in the snow cover $(10$ to $66 \mathrm{~cm})$ was compared with the variation of soil surface temperature. Soil surface temperature was maintained near $0^{\circ} \mathrm{C}$ during

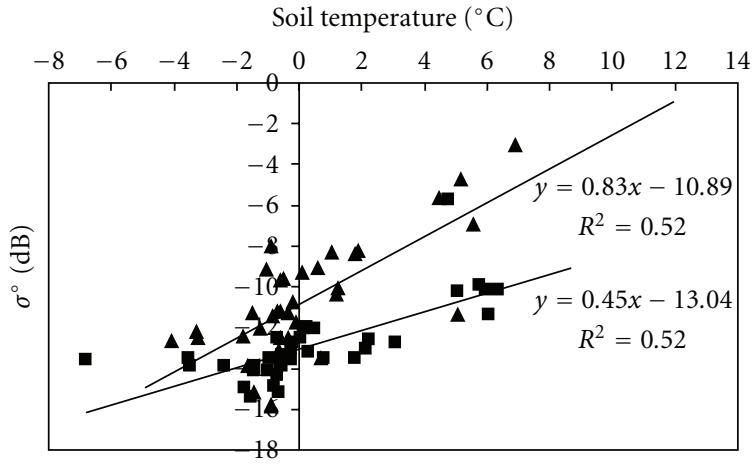

FIGURE 4: Linear regression models between backscattering coefficient, $\sigma^{\circ}$, with ground measured soil temperature $(0-5 \mathrm{~cm}$ depth) for tilled fields (triangle) and untilled fields (square).

long periods. Generally, snow cover played an important role by maintaining heat on the soil surface, even when the air temperature dropped below $-10^{\circ} \mathrm{C}$. Thaw started in midMarch (Figure 3(c)).

The winter of 2006 was warmer. In March, with the onset of snowmelt, the shallow unfrozen ground quickly became saturated up to the surface. Flow occurred overland because the ground had limited storage capacity (Figure 3(c)).

3.2. Backscattering Coefficients and Ground Soil Measurements. Figure 4 illustrates the relationship between backscattering coefficients $\left(\sigma^{\circ}\right)$ and the soil temperature for data acquired during 2004, 2005, and 2006. Since the spatial resolution of the developed model is approximately $9 \mathrm{~m}$, the radar signal mean values were compared with the mean values of the ground soil temperature and the soil moisture (Figure 5) taken from the same sampling cells. It is assumed that surface roughness was homogenous for each considered class (tilled and untilled). Thus, a regression line was fitted to all points belonging to each class (tilled and untilled) (Figure 4). For both the tilled and untilled class, the coefficient of determination $\left(R^{2}\right)$ was 0.52 , which is considered satisfactory. There is a comparable correlation between $\sigma^{\circ}$ and soil temperature for surface soil temperatures below $0^{\circ} \mathrm{C}$, which progressively becomes weaker with increasing surface soil temperature. When the soil temperature is below $0^{\circ} \mathrm{C}$, there is no significant difference in the $\sigma^{\circ}$ and the soil temperature relationship for the tilled and the untilled fields. However, when the soil temperature is above $0^{\circ} \mathrm{C}$, one can distinguish two relationships wherein the $\sigma^{\circ}$ for the tilled fields is higher than that of the untilled fields. This can be explained by the high sensitivity of the backscattered signal to soil roughness when soil moisture increased. Given that the range of observations from this study is $-7^{\circ} \mathrm{C}$ to $7^{\circ} \mathrm{C}$, soil moisture would have decreased when the soil was frozen, and thus the soil would have been dry [23, 33]. Consequently, the radar signal would penetrate the soil with minimal effect on soil roughness. However, when soil temperature increases, soil moisture content also increases, and consequently, the backscattered signal increases and can 


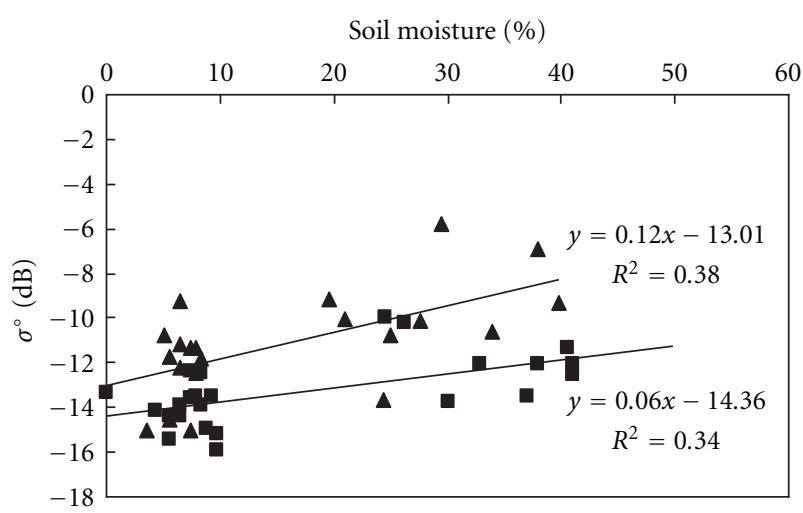

(a)

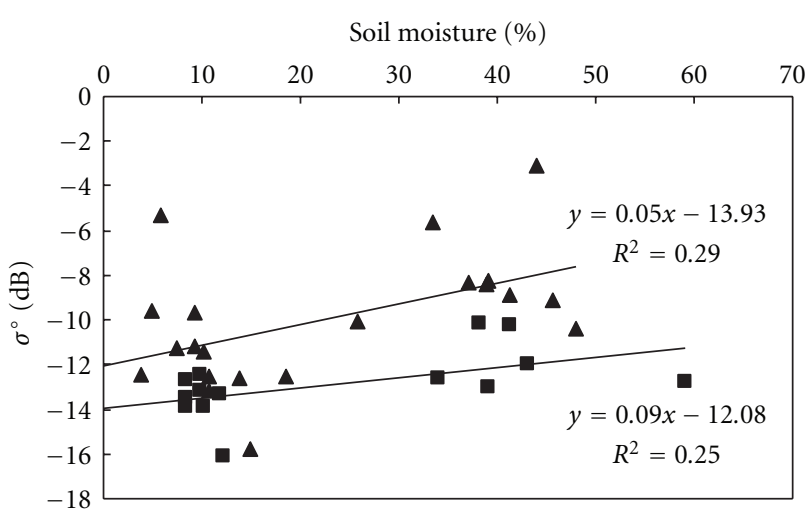

(b)

Figure 5: Linear regression models between backscattering coefficient, $\sigma^{\circ}$, with ground measured soil moisture $(0-5 \mathrm{~cm}$ depth) for soil drainage types: (a) moderate to good drainage and (b) poor drainage. Symbols for each field class; tilled (triangle), untilled (square).

be significantly affected by field surface conditions (tilled or untilled). This explains the increase in the backscattering coefficient for the tilled fields.

As presented in Figure 5, a regression analysis was also performed between $\sigma^{\circ}$ and soil moisture, separately for two drainage groups (good; moderately to well-drained soils: poor; poorly drained soils), according to each land use class (tilled versus untilled fields). The coefficient of determination $\left(R^{2}\right)$ between $\sigma^{\circ}$ and surface soil moisture was 0.38 for tilled and 0.34 for untilled fields with good soil drainage. For the poorly drained soils, the $R^{2}$ value was 0.29 for tilled and 0.25 for untilled fields (Figure 5). These correlation coefficients were lower than those previously reported [57, 58]. Empirical relationships between $\sigma^{\circ}$ and near-surface water content show considerable scatter, and the relationships vary with land use (tilled/untilled). One probable reason for the absence of a good relationship between $\sigma^{\circ}$ and near-surface water content is that soils show different relationships between soil dielectric properties and soil water content. This is due to differences in particle-size distribution affecting the partitioning between bound and free water [59]. Another reason behind the observed discrepancy is the directional effects of the rows on the SAR return signal which increases when the row direction is almost perpendicular to the SAR antenna, as for fields 1, 2, and 12 (Figure 1). This effect makes the return signal stronger compared with other fields. The accuracy of the proposed relationship for estimating soil moisture is considered satisfactory, because cartographic and measurement errors are common in this type of analysis. In spite of the large variation in radar and volumetric moisture content data, the positive correlation between $\sigma^{\circ}$ and volumetric soil water content shows that the backscattered radar signals are related to soil moisture. Generally, the backscattering coefficient was found to vary from -8 to $-16 \mathrm{~dB}$ for volumetric soil moisture content that ranged from $42 \%$ to $12 \%$. For tilled fields, the average of $\sigma^{\circ}$ is relatively high $(-10 \mathrm{~dB})$ compared with untilled fields $(-12 \mathrm{~dB})$ with a $R^{2}$ of 0.37 .

At first, a decrease of $\sigma^{\circ}(3 \mathrm{~dB})$ was noted between December 2, 2003, and January 19, 2004, for all fields (data not shown) when the soil was frozen (air temperature = $-11^{\circ} \mathrm{C}$ ). The backscattering coefficient decreased by $3 \mathrm{~dB}$ for the Mawcook, sandy loam soils in the untilled field 1. For the tilled field 2 (same soil type), the backscattering coefficient decreased by $2 \mathrm{~dB}$ where the frost depth increased from 8 to $50 \mathrm{~cm}$. The decreased backscattering coefficient over the Bras d'Henri watershed was associated with a decreased surface soil temperature below $0^{\circ} \mathrm{C}$, and depended on soil type. On November 2, 2004, a strong backscattering coefficient, of about $-5 \mathrm{~dB}$, was recorded; this increase may be explained by increased soil moisture content (about 40\%) and amplification as a result of surface roughness. The portion of the transmitted energy from the soil surface to the sensor was larger when the soil was wet because of the strong dielectric differential between water and air. The same phenomenon occurred again on February 6, 2005, when an increased backscattering coefficient was also noted (i.e., $\sigma^{\circ}=$ $-5 \mathrm{~dB}$ ) in most fields except for fields $1,2,9$, and 14 (results not shown). In this case, the air temperature was recorded at $2{ }^{\circ} \mathrm{C}$ for the satellite pass; the snow cover was between 0 and $9 \mathrm{~cm}$, while the frost depth was about $50 \mathrm{~cm}$. This increase in the backscattered signal was not associated with the thaw but rather with an increase in moisture on the soil surface.

3.3. Frozen Soil Mapping Algorithm. The linear regression in this study was used to identify different values of backscattering coefficients $\left(\sigma^{\circ}\right)$ that can be used to distinguish between frozen and unfrozen fields for different soil conditions. Three categories were considered for each soil series, as follows: tilled frozen soils, untilled frozen soils, and frost-free soils. The threshold for determining whether a field was frozen or not was predicted by the $\sigma^{\circ}$ value corresponding to the zero temperature from the regression model for each soil group (i.e., soil series having similar parent material, family particlesize, and drainage conditions). Thus, the soil condition (frozen or not) was identified by applying the predicted $\sigma^{\circ}$ thresholds for each delineation on the soil map.

In this temporal study, we assumed that soil surface roughness was constant over time for each land use type 


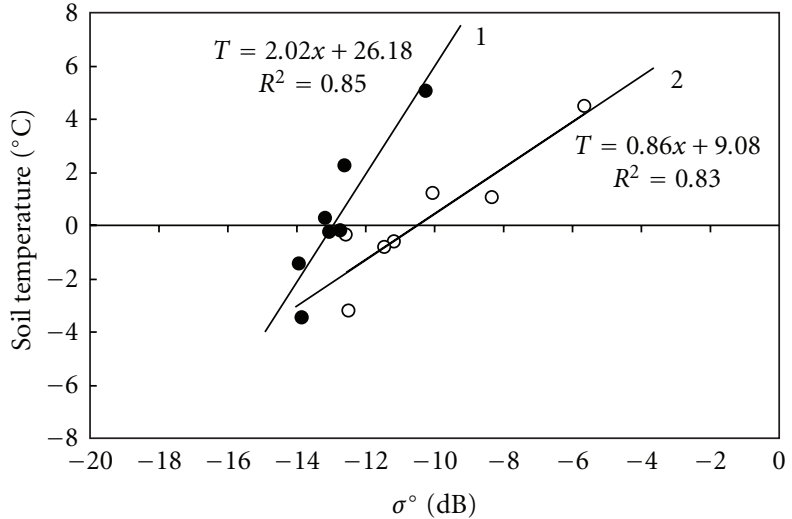

(a)

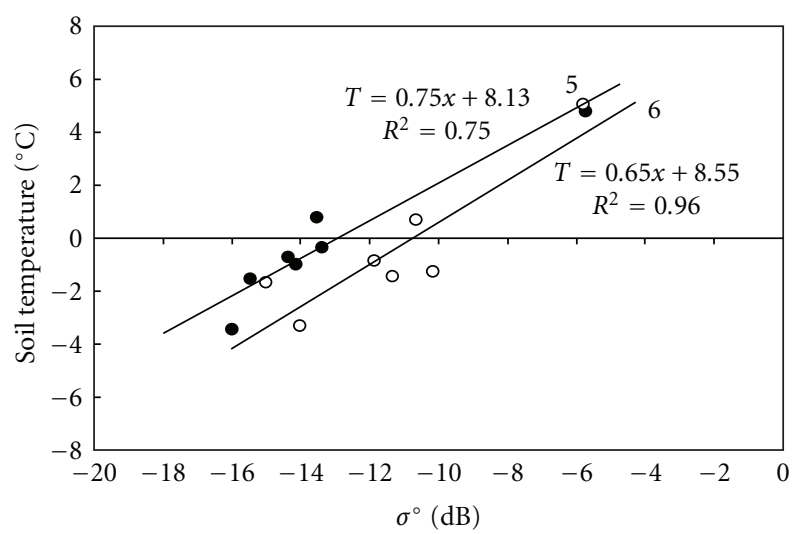

(c)

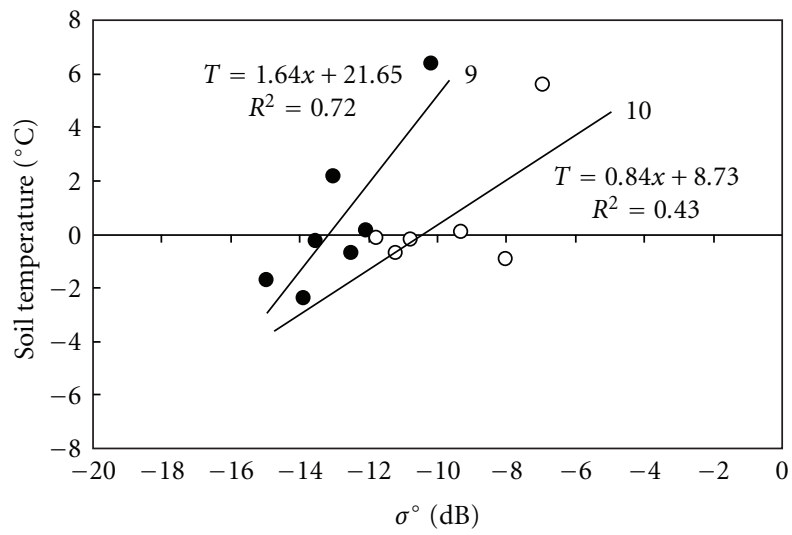

(e)

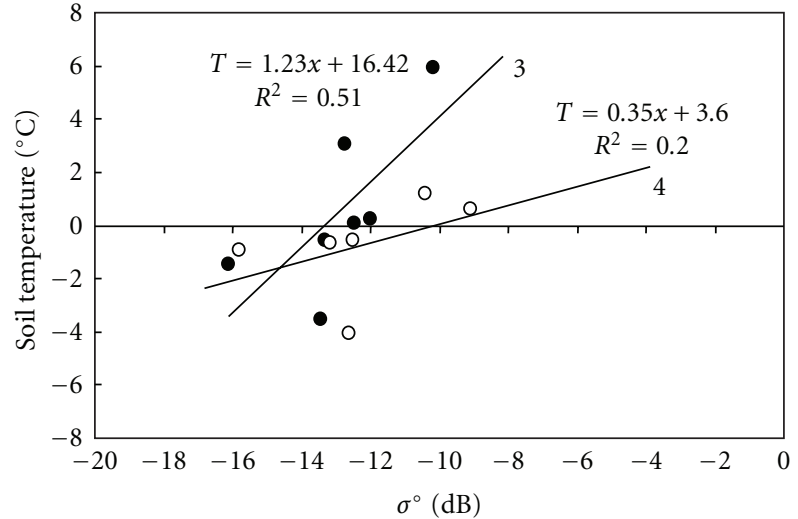

(b)

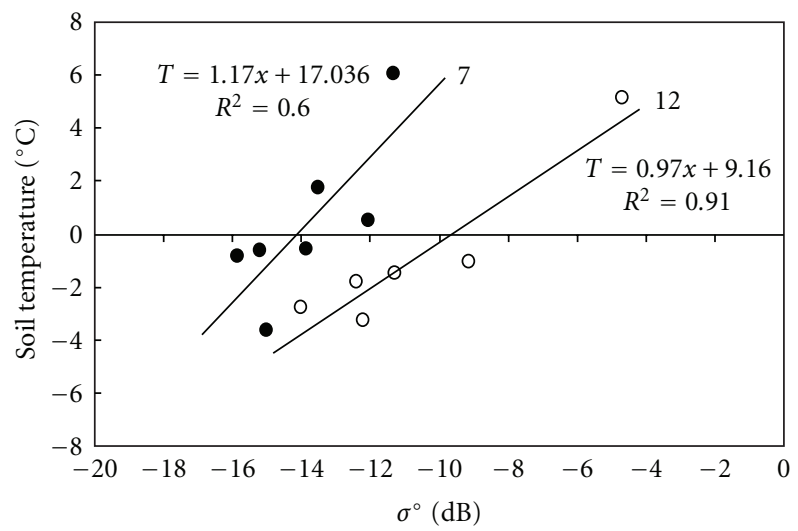

(d)

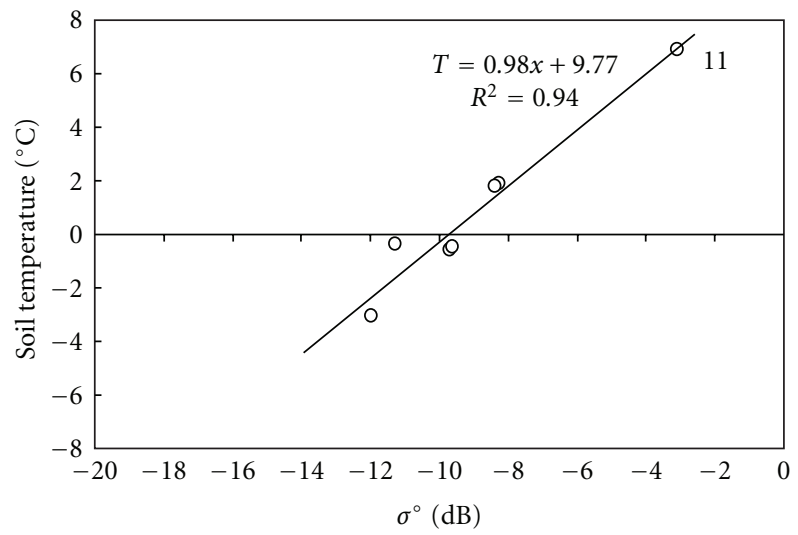

(f)

FIGURE 6: Linear regression models describing the variation of soil temperature measured at $5 \mathrm{~cm}$ in relation to the backscattering coefficient, $\sigma^{\circ}$, according to soil type: (a) Mawcook, sandy loam, (b) Le Bras, loam, (c) Neubois, loam, (d) Beaurivage, sandy loam, (e) Woodbridge, loam, (f) organic soil, and land use type; tilled fields $(\bigcirc)$ and untilled fields $(\bullet)$.

(untilled versus tilled fields) during the same winter season, because the soil surface would not be ploughed nor naturally modified before spring snowmelt [60]. Under this assumption, it is possible to consider that for each field, the backscattering coefficient $\left(\sigma^{\circ}\right)$ was related to soil surface moisture status [31]. In this section, the regression analysis was performed between the soil temperature at $5 \mathrm{~cm}$ and $\sigma^{\circ}$, taking the soil series into account.
For the 12 fields under study, the average $\sigma^{\circ}$ was extracted and plotted versus the in situ measured soil temperature (Figure 6). Different simple linear regression models were performed for different soil types as well as for tilled and untilled soils. Figure 6 show that $\sigma^{\circ}$ increased as soil temperature increased, indicating a positive correlation between $\sigma^{\circ}$ and soil temperature. The soil types under study gave different $R^{2}$ values: 0.80 for Mawcook, sandy loam 


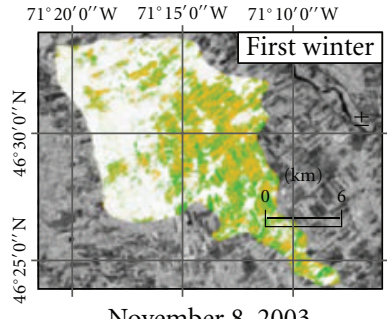

November 8, 2003

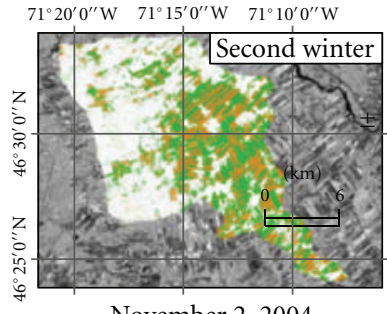

November 2, 2004

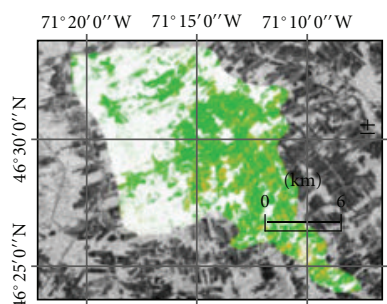

February 25, 2006

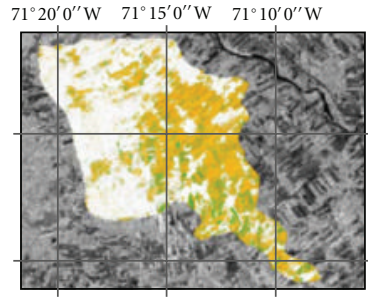

December 2, 2003

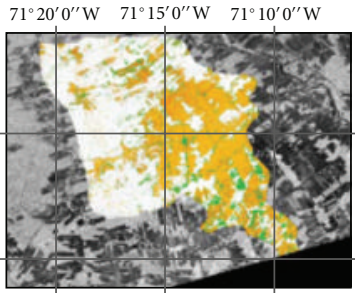

January 13, 2005

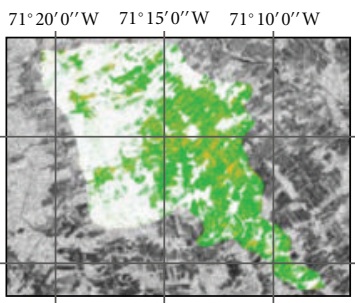

March 21, 2006

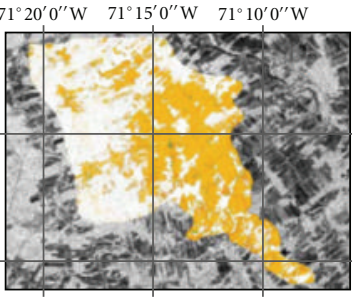

January 19, 2004

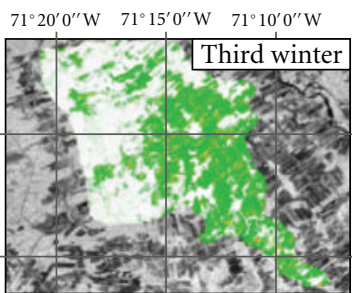

January 8, 2006

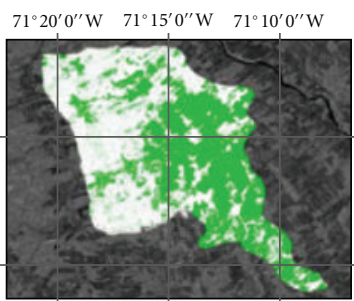

April 14, 2006

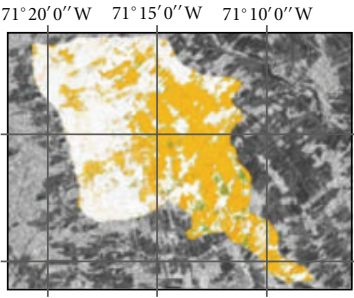

February 29, 2004

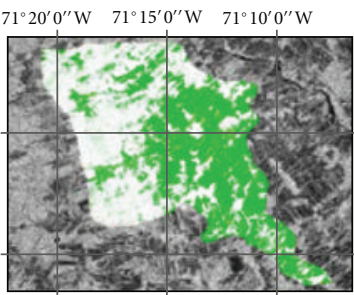

February 1, 2006

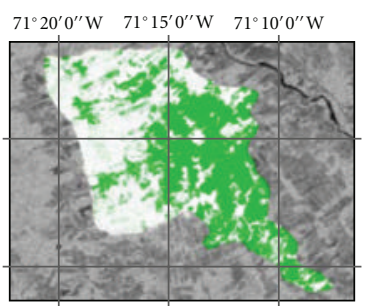

May 8, 2006

FIGURE 7: Maps of the frozen/unfrozen soil conditions in the Bras d'Henri watershed (2003-2006) using 12 RADARSAT-1 SAR images. Green: unfrozen soils, orange: tilled frozen soils, yellow: untilled frozen soils, and white: mask applied for forest area.

(fields 1 and 2), 0.74 for Beaurivage, sandy loam (fields 7 and 12), 0.85 for Neubois, loam (fields 5 and 6), 0.55 for Woodbridge, loam (fields 9 and 10), 0.35 for Le Bras, loam (fields 3 and 4), and 0.94 for the organic soil (field 11). A low coefficient of determination $\left(R^{2}=0.20\right)$ was determined for Le Bras, loam, especially in the corn field after harvest (fields 4). This result can be explained by the interaction between the radar signal and dried corn residue and stalks remaining in the field after harvest. The moisture content of these stalks and residue may have varied throughout the field and during the fall season, which would increase the uncertainty of the estimated backscatter values. As the soil surface temperature decreased below $0^{\circ} \mathrm{C}$, the $\sigma^{\circ}$ decreased by 3 to $5 \mathrm{~dB}$ depending on soil type. Also, the reader should note that for each soil type class, $\sigma^{\circ}$ for the tilled fields (fields 2, 4, 6, 10, 11, and 12) were always greater, by at least $2 \mathrm{~dB}$, than $\sigma^{\circ}$ for the untilled fields. When the soil is frozen, it has a dielectric constant similar to dry soil. In this case, the signal penetrates the soil and is less sensitive to soil surface roughness. However, when the soil is unfrozen under the snow pack, soil water content increases, and the signal becomes more sensitive to soil surface roughness.

The regression equations given in Figure 6 identify the radar backscattering coefficient thresholds, which are used to differentiate frozen and unfrozen soils. These thresholds represent the backscattering values that correspond to soil temperatures below $0^{\circ} \mathrm{C}$ (Table 7 ). Several maps of nearsurface frozen soil conditions (frozen versus unfrozen soils) for the Bras d'Henri watershed were created for the winter seasons 2003-2004, 2004-2005, and 2005-2006 (Figure 7).

It should be emphasized that although the models developed in this study were applied to Bras d'Henri using available data to demonstrate models usefulness, however, more data should be acquired to update the developed models.

\subsection{Frozen Soil Maps Derived from the Classification Algo-} rithm. The classification algorithm developed in this paper was applied to the Bras d'Henri watershed $\left(167 \mathrm{~km}^{2}\right)$ to identify frozen and unfrozen soils for all agricultural fields distributed over the entire watershed. To visualize the results, a color scale was used to display the near-surface frozen/unfrozen soils. Untilled frozen soils are in yellow, tilled frozen soils in orange, and unfrozen soils in green. A white mask was applied to cover the forest area that was excluded from the study (Figure 7). There are notable interannual variations in frozen soil distribution between each winter season over the Bras d'Henri watershed. Frozen soils covered a large area in 2004 (85\%) and 2005 (74\%) but covered only $35 \%$ of the area in 2006 (Table 8 ).

The minimum soil temperature at $5 \mathrm{~cm}$ was recorded as $-7^{\circ} \mathrm{C}$ for the untilled Beaurivage soils on February 6, 2005; the maximum was $13^{\circ} \mathrm{C}$ at $1 \mathrm{~cm}$ for the tilled organic soils 
TABLE 4: Classification results of six selected RADARSAT-1 SAR images compared with soil temperature at the 12 training/validation study fields.

\begin{tabular}{lcccccc}
\hline \multirow{2}{*}{ Total } & & \multicolumn{3}{c}{ Classification results } \\
& & Frozen & Unfrozen & Total & Success (\%) & Omission (\%) \\
\hline \multirow{3}{*}{ Ground observations } & Frozen & 33 & 5 & 38 & 86.8 & 13.2 \\
& Unfrozen & 2 & 32 & 34 & 94.1 & 90.3 \\
\hline & Total & 35 & 37 & 72 & Kappa $=0.81$ \\
\hline
\end{tabular}

TABLE 5: Classification results of six selected RADARSAT-1 SAR images compared with soil temperature measurements at the 12 training/validation study fields, by land use.

\begin{tabular}{|c|c|c|c|c|c|c|}
\hline & & \multicolumn{5}{|c|}{ Classification results } \\
\hline & & Frozen & Unfrozen & Total & Success $(\%)$ & Omission (\%) \\
\hline \multicolumn{7}{|c|}{ Tilled fields } \\
\hline \multirow{4}{*}{ Ground observations } & Frozen & 17 & 3 & 20 & 85 & 15 \\
\hline & Unfrozen & 1 & 15 & 16 & 94 & 6 \\
\hline & Total & 18 & 18 & 36 & 89 & \\
\hline & Commission (\%) & 6 & 17 & & \multicolumn{2}{|c|}{ Kappa $=0.78$} \\
\hline \multicolumn{7}{|c|}{ Untilled fields } \\
\hline \multirow{4}{*}{ Ground observations } & Frozen & 16 & 2 & 18 & 89 & 11 \\
\hline & Unfrozen & 1 & 17 & 18 & 94 & 6 \\
\hline & Total & 17 & 19 & 36 & 92 & \\
\hline & Commission (\%) & 6 & 11 & & \multicolumn{2}{|c|}{ Kappa $=0.83$} \\
\hline
\end{tabular}

on April 21, 2004. Soil temperatures showed strong variation near the surface (following changes in air temperature) but varied less at greater depths. The unfrozen moisture content increased in frozen soils with increasing soil temperatures at all depths and, more markedly, after the onset of snowmelt when soil temperatures increased rapidly (Figure 3).

In general, freezing starts in November and moves gradually toward the watershed depending on soil type, snow cover, and air temperature. The soil temperature decreased gradually as the frozen front progressed. When air temperature decreased in November, soil temperatures decreased quite uniformly throughout the unfrozen soil profile, and freezing set in abruptly after the $0^{\circ} \mathrm{C}$ isotherm was encountered. The progress of freezing apparently reflected the heterogeneity of the soil. At a given negative temperature, the quantity of unfrozen water varied considerably with soil type and was greater for soils with a finer texture. Furthermore, the greater organic matter content of organic soils (field 11) reduced both their soil heat capacity and soil thermal conductivity [61]. Also, they retained more water and the latent heat conductivity of water is greater than air.

This result may be understood as a complex interaction between thermal and hydraulic conductivities, both of which decrease with decreasing unfrozen water content. It is also related to the larger amount of latent heat that is released from soils with high water content. Soils with low water content (Beaurivage, loamy sand (field 14)) may be expected to initially freeze earlier because the release of latent heat is less. The maps show that the distribution of the frozen areas over the watershed correlate well with soil type distribution and the interannual variation of air temperature and snow cover. The detectability of the freezing onset seems to be sensitive to land use (i.e., tilled versus untilled fields). On November 2, 2004, freezing had already occurred, particularly in the tilled fields, because the surface was directly exposed to low air temperatures, due to the low snow accumulation and because tillage promoted good drainage, which consequently accelerated the heat transfer through the porous soil.

When the near-surface frozen extension over the Bras d'Henri watershed is compared over the three winter seasons (2003-2004 to 2005-2006), the main difference between them is snow cover depth; it was substantial during the third winter season $(\sim 45 \mathrm{~cm})$ but was $30 \mathrm{~cm}$ for the first winter and only $17 \mathrm{~cm}$ for the second winter. These results show that the presence of seasonal snow cover during the cold season has a significant influence on the ground thermal regime. In seasonally frozen ground regions, snow cover can substantially reduce the seasonal freezing depth. In fact, snow cover plays an insulating role by maintaining surface soil near the freezing point $[62,63]$. Therefore, a frozen soil under a seasonal snow cover could eventually thaw during winter even though it may have been frozen before the snow cover occurred.

3.5. Validation of the Classification Algorithm. The empirical algorithm validation is based on the soil temperature data of the top $5 \mathrm{~cm}$ soil layer for the six RADARSAT-1 images acquired between January and May 2006. Using the 12 training/validation fields of the third winter season, confusion 
TABLE 6: Classification results of six selected RADARSAT-1 SAR images compared with soil temperature at the 12 training/validation study fields, by acquisition date.

\begin{tabular}{|c|c|c|c|c|c|c|}
\hline & & \multicolumn{5}{|c|}{ Classification results } \\
\hline & & Frozen & Unfrozen & Total & Success (\%) & Omission (\%) \\
\hline \multicolumn{7}{|c|}{ January 8, 2006} \\
\hline \multirow{4}{*}{ Ground observations } & Frozen & 11 & 1 & 12 & 92 & 8 \\
\hline & Unfrozen & 0 & 0 & 0 & 100 & 0 \\
\hline & Total & 11 & 1 & 12 & 92 & 8 \\
\hline & Commission (\%) & 0 & 100 & 8 & Kappa $=\mathrm{NA}^{(\mathrm{a})}$ & \\
\hline \multicolumn{7}{|c|}{ February 1, 2006} \\
\hline \multirow{4}{*}{ Ground observations } & Frozen & 7 & 1 & 8 & 88 & 12 \\
\hline & Unfrozen & 1 & 3 & 4 & 75 & 25 \\
\hline & Total & 8 & 4 & 12 & 83 & 17 \\
\hline & Commission (\%) & 13 & 25 & $17 \%$ & Kappa $=0.63$ & \\
\hline \multicolumn{7}{|c|}{ February 26, 2006} \\
\hline \multirow{4}{*}{ Ground observations } & Frozen & 11 & 1 & 12 & 92 & 8 \\
\hline & Unfrozen & 0 & 0 & 0 & 100 & 0 \\
\hline & Total & 11 & 1 & 12 & 92 & 8 \\
\hline & Commission (\%) & 0 & 100 & 8 & $\mathrm{Kappa}=\mathrm{NA}^{(\mathrm{a})}$ & \\
\hline \multicolumn{7}{|c|}{ March 21, 2006} \\
\hline \multirow{4}{*}{ Ground observations } & Frozen & 4 & 2 & 6 & 67 & 33 \\
\hline & Unfrozen & 1 & 5 & 6 & 83 & 17 \\
\hline & Total & 5 & 7 & 12 & 75 & 25 \\
\hline & Commission $(\%)$ & 20 & 29 & 25 & Kappa $=0.50$ & \\
\hline \multicolumn{7}{|c|}{ April 14, 2006} \\
\hline \multirow{4}{*}{ Ground observations } & Frozen & 0 & 0 & 0 & 100 & 0 \\
\hline & Unfrozen & 0 & 12 & 12 & 100 & 0 \\
\hline & Total & 0 & 12 & 12 & 100 & 0 \\
\hline & Commission (\%) & 0 & 0 & 0 & $\mathrm{Kappa}=\mathrm{NA}^{(\mathrm{a})}$ & \\
\hline \multicolumn{7}{|c|}{ May 8, 2006} \\
\hline \multirow{4}{*}{ Ground observations } & Frozen & 0 & 0 & 0 & 100 & 0 \\
\hline & Unfrozen & 0 & 12 & 12 & 100 & 0 \\
\hline & Total & 0 & 12 & 12 & 100 & 0 \\
\hline & Commission (\%) & 0 & 0 & 0 & Kappa $=\mathrm{NA}^{(\mathrm{a})}$ & \\
\hline
\end{tabular}

${ }^{(a)}$ Because only one class is represented, the Kappa coefficient cannot be calculated (division by zero).

matrices were computed to compare results from the proposed algorithm that classified soils as being frozen with the in situ soil temperatures. The analysis consisted of examining and displaying errors of commission and omission and the overall classification accuracy. From these percentages, a performance measure known as Kappa was calculated. The Kappa coefficient $(\kappa)$ was used to represent the overall classification agreement [64]. Kappa values range from -1 to 1 ; a value of zero indicates that the effect of the classifier equals chance agreement, and a value of 1 indicates a perfectly effective classification without a contribution from chance agreement. Any negative value indicates a poor classification in which chance agreement is more important than the classification effect. Therefore, a Kappa value of 0.75 or greater indicates a very good to excellent classification performance [65].

Table 4 contains the full contingency table as evidence of classification results for all the six SAR images. The overall classification accuracy was $90 \%(\kappa=0.81)$ over the Bras
d'Henri watershed. According to classification results, frozen soils had an average classification accuracy of $87 \%$. The highest classification accuracy of $94 \%$ was obtained for the unfrozen soils, with only two fields incorrectly classified, while five fields were incorrectly classified for frozen soils. It is apparent that the soil attributes measured in the field were better suited for discerning the near-surface frozen and unfrozen status. In the next step, classification results were compared with land use, that is, tilled versus untilled fields (Table 5). The lowest individual class accuracy of $89 \%(\kappa$ $=0.78$ ) was obtained for the tilled fields. This result may be explained by the higher within-class variability resulting from a greater diversity of tillage practices and orientation settings where freezing occurred and which would have increased the backscattering signal.

Table 6 presents the classification results for each RADARSAT-1 image. The best classification accuracy (100\%) was achieved when all fields were thawed (March 2005). On 
TABLE 7: Radar backscattering coefficient thresholds $(\mathrm{dB})$ used to differentiate frozen from unfrozen soils taking soil and land use type into account over the Bras d'Henri watershed.

\begin{tabular}{lcc}
\hline Soil types (field number) & Tilled & Field type \\
\hline Mawcook, sandy loam $(1,2)$ & -10.5 & Untilled \\
Le Bras, loam $(3,4)$ & -11.8 & -12.9 \\
Neubois, loam $(5,6)$ & -10.8 & -13.1 \\
Beaurivage, sandy loam to loamy sand $(7,12,14)$ & -9.5 & -13.2 \\
Woodbridge, loam $(9,10)$ & -9.9 & -13.0 \\
Organic soils $(11)$ & -9.8 & -12.8 \\
\hline
\end{tabular}

(a) Because the untilled field is not represented.

TABLE 8: Distribution of frozen/unfrozen soils for the12 radar images acquired during the three winter seasons (2003-2004 to 2005-2006) over the Bras d'Henri watershed, by land use.

\begin{tabular}{|c|c|c|c|c|}
\hline Winter season & Date (dd/mm/yyyy) & Untilled frozen soils (\%) & Tilled frozen soils (\%) & Unfrozen soils (\%) \\
\hline \multirow{4}{*}{ First } & $08 / 11 / 2003$ & 31 & 34 & 35 \\
\hline & $02 / 12 / 2003$ & 39 & 43 & 18 \\
\hline & $19 / 01 / 2004$ & 47 & 49 & 4 \\
\hline & $29 / 02 / 2004$ & 43 & 52 & 5 \\
\hline \multirow{2}{*}{ Second } & $02 / 11 / 2004$ & 31 & 38 & 31 \\
\hline & $13 / 01 / 2005$ & 39 & 40 & 21 \\
\hline \multirow{6}{*}{ Third } & $08 / 01 / 2006$ & 19 & 21 & 60 \\
\hline & $01 / 02 / 2006$ & 10 & 12 & 78 \\
\hline & $25 / 02 / 2006$ & 24 & 27 & 49 \\
\hline & $21 / 03 / 2006$ & 23 & 29 & 48 \\
\hline & $14 / 04 / 2006$ & 10 & 14 & 76 \\
\hline & 08/05/2006 & 9 & 11 & 80 \\
\hline
\end{tabular}

March 2006, two out of six frozen fields were classified as unfrozen. The resulting classification accuracy is equal to $75 \%$.

It is important to note some limitations in applying the proposed approach. First, the mapping of frozen soil is mainly realised during winter under the presence of a snow cover. When the snow is wet, the backscattered signal cannot penetrate the snow cover, and therefore, we cannot have reliable information about the soil surface status. Thus, SAR radar images should be acquired under dry or refrozen snow cover. Second, the proposed methodology assumes that roughness parameters will be time invariant. Although this may be a reasonable assumption within the same season, it is known that roughness in agricultural fields tends to decrease over time as a result of weathering and rainfall erosion. Then, it would be necessary to have an annual map of land use. Finally, agricultural fields have a periodic row structure that affects the surface backscattering values.

\section{Conclusions and Future Perspectives}

In this study, a classification algorithm was developed to classify the near-surface agricultural soil under snow cover as being frozen or unfrozen using RADARSAT-1 images. The developed algorithm is based on linear regression analysis. Regression models were performed for different soil types and land uses to identify a soil-freezing threshold. This threshold was identified by establishing a relationship between the backscattering coefficient and the soil temperature measured at $5 \mathrm{~cm}$ below the soil surface. The coefficient of determination obtained for the regression models varies between 0.2 and 0.96 .

The developed algorithm was validated by field measurements using the Kappa index. Results indicate that there is good association between image-derived surface soil status (frozen/unfrozen) and measured field soil temperature. Results of the Kappa index show that accuracy varies between $75 \%$ and $100 \%$. Excellent accuracy values were obtained for untilled agricultural fields. The main discrepancies are associated with later stages of snowmelt, especially in March, when the frozen and unfrozen fringe is not stable.

The studied fields were stratified into two land use classes (tilled and untilled fields). It was found that the backscattering coefficient from tilled fields was greater than that from the untilled fields. These results may indicate that surface roughness, mainly caused by soil ploughing, plays an important role. Radar signals are probably responsive to multiple bounces by the near-surface rock fragments when they penetrate a few centimetres below ground surface, in addition to the scattering due to surface roughness. 
Important observations were made in the monitoring of the interannual variations of soil temperature according to the atmospheric conditions and pedological attributes, and also in the monitoring of surface status.

The conditions under which the model was developed, applied, and validated are best suited to its application in agricultural areas where the vegetation is sparse, snow cover is dry, and the surface roughness does not change during the winter. In this study, we consider that soil surface roughness is constant or slightly altered during the winter season, since no agricultural activity is undertaken. However, soil surface roughness can change from year to year due to land use changes. This does not really affect the algorithm developed here, because a land use stratification is realised before applying the classification algorithm.

Of note, for higher soil temperatures than those observed in this study, soil moisture content may decrease (the soil may be considered dry), which allows the penetration of the backscatter signal into the soil; this will decrease the backscatter coefficient. However, classification between frozen and unfrozen soils is mainly based on a small range of soil temperatures around $0^{\circ} \mathrm{C}$.

The new approach developed in this study may be considered a first step for classifying soil surface frozen/unfrozen status. Clearly, additional validations should be done for other similar watersheds. Another problem concerns the status of the soil surface under wet snow. This weakness is a limiting factor, because the radar return cannot necessarily be attributed to effects from the liquid soil water content. Additional research should concentrate on the retrieval of soil frozen/unfrozen status which may include the effects of temporal surface modification. To broaden the applicability of the model to other watersheds, additional validation work is needed. In particular, future research should investigate the application of the model to a broader range of soil types and moisture conditions. Further, the method developed in this study is applied for monopolarization C-band radar image and its applicability for multipolarizations and others radar frequencies needs to be determined. Multipolarisations SAR sensors such as RADARSAT-2 (operational since May 2008) can provide input for classification schemes from different scattering mechanisms. When data is acquired in polarimetric mode, both the amplitude and phase information of the SAR signal are retained; the use of this information provides input for classification algorithms. Hence, it will be possible to extract information on land use directly from images, which may make it possible to systematically update land cover maps and monitor land conditions.

\section{Acknowledgments}

This study is cofinanced by Agriculture and Agri-Food Canada and the Canadian Space Agency through the Government Related Initiative Program (GRIP). The authors gratefully acknowledge Dr. Karem Chokmani, Yves Gauthier, Stéphane Savary, Veronique Beaulieu, and Lisa-Marie Pâquet from INRS-ETE, Nadia Goussard, Mario Deschênes, and André Martin from AAFC, and the agri-environmental counsellors of the Club de fertilisation de la Beauce for their expertise and technical assistance.

\section{References}

[1] N. C. Hansen, S. C. Gupta, and J. F. Moncrief, "Snowmelt runoff, sediment, and phosphorus losses under three different tillage systems," Soil and Tillage Research, vol. 57, no. 1-2, pp. 93-100, 2000.

[2] G. Y. Niu and Z. L. Yang, "Effects of frozen soil on snowmelt runoff and soil water storage at a continental scale," Journal of Hydrometeorology, vol. 7, no. 5, pp. 937-952, 2006.

[3] G. Bélanger, Y. Castonguay, A. Bertrand et al., "Winter damage to perennial forage crops in eastern Canada: causes, mitigation, and prediction," Canadian Journal of Plant Science, vol. 86, no. 1, pp. 33-47, 2006.

[4] B. Ulén, "Concentrations and transport of different forms of phosphorus during snowmelt runoff from an illite clay soil," Hydrological Processes, vol. 17, no. 4, pp. 747-758, 2003.

[5] D. C. Garen and D. S. Moore, "Curve number hydrology in water quality modeling: uses, abuses, and future directions," Journal of the American Water Resources Association, vol. 41, no. 2, pp. 377-388, 2005.

[6] E. Van Bochove, G. Thériault, P. Rochette, H. G. Jones, and J. W. Pomeroy, "Thick ice layers in snow and frozen soil affecting gas emissions from agricultural soils during winter," Journal of Geophysical Research, vol. 106, no. 19, pp. 23061-23071, 2001.

[7] K. M. Hinkel, R. F. Paetzold, F. E. Nelson, and J. G. Bockheim, "Patterns of soil temperature and moisture in the active layer and upper permafrost at Barrow, Alaska: 1993-1999," Global and Planetary Change, vol. 29, no. 3-4, pp. 293-309, 2001.

[8] U. Hillard, V. Sridhar, D. P. Lettenmaier, and K. C. McDonald, "Assessing snow melt dynamics with NASA scatterometer (NSCAT) data and a hydrologic process model," Remote Sensing of Environment, vol. 86, no. 1, pp. 52-69, 2003.

[9] H. G. Jones, J. W. Pomeroy, D. A. Walker, and R. W. Hoham, Snow Ecology: An Interdisciplinary Examination of SnowCovered Ecosystems, Cambridge University Press, Cambridge, Mass, USA, 2001.

[10] J. Khaldoune, M. Bernier, E. Van Bochove, and M. C. Nolin, "Détection du gel et non-gel du sol en utilisant le radar polarimétrique à synthèse d'ouverture," Canadian Journal of Remote Sensing, vol. 34, no. 4, pp. 418-429, 2008.

[11] T. Zhang and R. L. Armstrong, "Soil freeze/thaw cycles over snow-free land detected by passive microwave remote sensing," Geophysical Research Letters, vol. 28, no. 5, pp. 763$766,2001$.

[12] B. Zuerndorfer and A. W. England, "Radiobrightness decision criteria for freeze/thaw boundaries," IEEE Transactions on Geoscience and Remote Sensing, vol. 30, no. 1, pp. 89-102, 1992.

[13] F. Bonn and G. Rochon, Précis de Télédétection: Principes et Méthodes. Vol. 1, Presse de l'Université du Québec/AUPELF, Ste-Foy, Québec, Canada, 1992.

[14] C. François, C. Ottlé, and L. Prévot, "Analytical parameterization of canopy directional emissivity and directional radiance in the thermal infrared. Application on the retrieval of soil and foliage temperatures using two directional measurements," International Journal of Remote Sensing, vol. 18, no. 12, pp. 2587-2621, 1997. 
[15] B. Coudert, C. Ottlé, and X. Briottet, "Monitoring land surface processes with thermal infrared data: calibration of SVAT parameters based on the optimisation of diurnal surface temperature cycling features," Remote Sensing of Environment, vol. 112, no. 3, pp. 872-887, 2008.

[16] J. L. Davis and A. P. Annan, "Ground-penetrating radar for high-resolution mapping of soil and rock stratigraphy," Geophysical Prospecting, vol. 37, no. 5, pp. 531-551, 1989.

[17] A. Pietroniro and R. Leconte, "A review of Canadian remote sensing applications in hydrology, 1995-1999," Hydrological Processes, vol. 14, no. 9, pp. 1641-1666, 2000.

[18] M. Bernier and J. P. Fortin, "The potential of times series of Cband SAR data to monitor dry and shallow snow cover," IEEE Transactions on Geoscience and Remote Sensing, vol. 36, no. 1, pp. 226-243, 1998.

[19] Y. Crevier, T. J. Pultz, T. I. Lukowski, and T. Toutin, "Temporal analysis of ERS-1 SAR backscatter for hydrology applications," Canadian Journal of Remote Sensing, vol. 22, no. 1, pp. 65-76, 1996.

[20] D. W. Leverington and C. R. Duguay, "A neural network method to determine the presence or absence of permafrost near Mayo, Yukon Territory, Canada," Permafrost and Periglacial Processes, vol. 8, no. 2, pp. 205-215, 1997.

[21] C. Lagacé and M. Bernier, "Développement d'une approche pour faire le suivi du gel saisonnier du sol sur le bassin de la rivière La Grande à partir de l'utilisation conjointe d'images SSM/I et RADARSAT," in Proceedings of the 57th Eastern Snow Conference, Syracuse, NY, USA, 2000.

[22] M. T. Hallikainen, F. T. Ulaby, M. C. Dobson, M. A. El-Rayes, and $\mathrm{L} . \mathrm{K}$. Wu, "Microwave dielectric behavior of wet soilpart I: empirical models and experimental observations," IEEE Transactions on Geoscience and Remote Sensing, vol. 23, no. 1, pp. 25-34, 1985.

[23] F. T. Ulaby, R. K. Moore, and A. K. Fung, Microwave Remote Sensing: Active and Passive: Volume III, Artech House, Deham, Mass, USA, 1986.

[24] C. Elachi, Introduction to the Physics and Techniques of Remote Sensing, John Wiley \& Sons, New York, NY, USA, 1987.

[25] E. J. M. Rignot, J. B. Way, C. Williams, and L. Viereck, "Radar estimates of aboveground biomass in boreal forests of interior Alaska," IEEE Transactions on Geoscience and Remote Sensing, vol. 32, no. 5, pp. 1117-1124, 1994.

[26] C. Doussan, L. Jouniaux, and J. L. Thony, "Variations of selfpotential and unsaturated water flow with time in sandy loam and clay loam soils," Journal of Hydrology, vol. 267, no. 3-4, pp. 173-185, 2002.

[27] E. T. Engman and N. Chauhan, "Status of microwave soil moisture measurements with remote sensing," Remote Sensing of Environment, vol. 51, no. 1, pp. 189-198, 1995.

[28] Y. Gauthier, "Détection par radar des zones à risque de gel pour les luzernières," in Actes du Colloque, Nouvelles Technologies en Agriculture, pp. 135-139, St-Jean-sur-Richelieu, Centre de Télédétection en Agro-Environnement, 1997.

[29] J. B. Way, R. Zimmermann, E. Rignot, K. McDonald, and R. Oren, "Winter and spring thaw as observed with imaging radar at BOREAS," Journal of Geophysical Research, vol. 102, no. 24, pp. 29673-29684, 1997.

[30] C. Lagacé, M. Bernier, and Y. Gauthier, "Cartographie du gel saisonnier du sol de taïga à partir d'images RSO de RADARSAT-1 et SSM/I de DMSP F-8," Télédétection, vol. 2, no. 3, pp. 161-175, 2001.

[31] F. T. Ulaby, R. K. Moore, and A. K. Fung, Microwave Remote Sensing: Active and Passive: Vol. 1. Fundamentals and Radiometry, Artech House, Dedham, Mass, USA, 1982.
[32] K. Boehnke and V. Wismann, "ERS scatterometer land applications: detecting soil thawing in Siberia," Earth Observation Quarterly, vol. 52, pp. 4-7, 1996.

[33] V. Wismann, "Monitoring of seasonal snowmelt on Greenland with ERS scatterometer data," IEEE Transactions on Geoscience and Remote Sensing, vol. 38, no. 4, pp. 1821-1826, 2000.

[34] J. S. Kimball, K. C. McDonald, A. R. Keyser, S. Frolking, and S. W. Running, "Application of the NASA scatterometer (NSCAT) for determining the daily frozen and nonfrozen landscape of Alaska," Remote Sensing of Environment, vol. 75, no. 1, pp. 113-126, 2001.

[35] L. -C. Lundin, "Hydraulic properties in an operational model of frozen soil," Journal of Hydrology, vol. 118, no. 1-4, pp. 289$310,1990$.

[36] A. Musy and M. Soutter, Physique du Sol, Presses polytechniques et universitaires Romandes, Lausanne, Switzerland, 1991.

[37] L. Nyberg, M. Stähli, P. E. Mellander, and K. Bishop, "Soil frost effects on soil water and runoff dynamics along a boreal forest transect: field investigations," Hydrological Processes, vol. 15, no. 6, pp. 909-926, 2001.

[38] J. F. Villasenor, D. R. Fatland, and L. D. Hinzman, "Change detection on Alaska's north slope using repeat-pass ERS-1 SAR images," IEEE Transactions on Geoscience and Remote Sensing, vol. 31, no. 1, pp. 227-236, 1993.

[39] T. J. Pultz, Y. Crevier, R. J. Brown, and J. Boisvert, "Monitoring local environment conditions with SIR-C/X-SAR," Remote Sensing of Environment, vol. 59, no. 2, pp. 248-255, 1997.

[40] J. B. Boisvert, Q. H. J. Gwyn, A. Chanzy, D. J. Major, B. Brisco, and R. J. Brown, "Effect of surface soil moisture gradients on modelling radar backscattering from bare fields," International Journal of Remote Sensing, vol. 18, no. 1, pp. 153-170, 1997.

[41] N. Baghdadi, P. Paillou, G. Grandjean, P. Dubois, and M. Davidson, "Relationship between profile length and roughness variables for natural surfaces," International Journal of Remote Sensing, vol. 21, no. 17, pp. 3375-3381, 2000.

[42] M. Zribi and M. Dechambre, "A new empirical model to retrieve soil moisture and roughness from C-band radar data," Remote Sensing of Environment, vol. 84, no. 1, pp. 42-52, 2003.

[43] M. M. Rahman, M. S. Moran, D. P. Thoma et al., "A derivation of roughness correlation length for parameterizing radar backscatter models," International Journal of Remote Sensing, vol. 28, no. 18, pp. 3995-4012, 2007.

[44] Q. P. Xu, J. B. Boisvert, N. Tremblay, F. Bonn, and R. J. Brown, "Évaluation des hyperfréquences pour le suivi de la teneur en eau et des cultures dans les histosols," Canadian Journal of Remote Sensing, vol. 24, no. 1, pp. 43-53, 1998.

[45] H. Geng, Q. H. J. Gwyn, B. Brisco, J. B. Boisvert, and R. J. Brown, "Mapping of soil moisture from C-band radar images," Canadian Journal of Remote Sensing, vol. 22, no. 1, pp. 117-126, 1996.

[46] L. Lamontagne, A. Martin, and M. C. Nolin, "Étude pédologique du bassin versant du Bras d'Henri (Québec)," Laboratoires de pédologie et d'agriculture de précision, Centre de recherche et de développement sur les sols et les grandes cultures, Service national d'information sur les terres et les eaux. Direction générale de la recherche. Agriculture et Agroalimentaire Canada, Québec, Canada, 2009.

[47] L. Lamontagne and M. C. Nolin, Cadre Pédologique de Référence pour la Corrélation des Sols, Bulletin d'extension numéro 7, Équipe pédologique du Québec, Centre de recherches et de développement sur les sols et les grandes cultures, Agriculture et Agroalimentaire Canada, Sainte-Foy, Canada, 1997. 
[48] G. C. Topp, "Soil water content," in Soil Sampling and Methods of Analysis, M. R. Carter, Ed., pp. 541-557, Canadian Society of Soil Science, Lewis Publishers, Boca Raton, Fla, USA, 1993.

[49] Soil Classification Working Group, The Canadian System of Soil Classification, Agriculture and Agri-Food Canada, Ottawa, Canada, 3rd edition, 1998, Publication 1646 (Revised).

[50] A. K. Fung and K. S. Chen, "Dependence of the surface backscattering coefficients on roughness, frequency and polarization states," International Journal of Remote Sensing, vol. 13, no. 9, pp. 1663-1680, 1992.

[51] N. Baghdadi, C. King, A. Bourguignon, and A. Remond, "Potential of ERS and Radarsat data for surface roughness monitoring over bare agricultural fields: application to catchments in Northern France," International Journal of Remote Sensing, vol. 23, no. 17, pp. 3427-3442, 2002.

[52] N. Holah, N. Baghdadi, M. Zribi, A. Bruand, and C. King, "Potential of ASAR/ENVISAT for the characterization of soil surface parameters over bare agricultural fields," Remote Sensing of Environment, vol. 96, no. 1, pp. 78-86, 2005.

[53] T. Toutin, "La correction géométrique rigoureuse : un mal nécessaire pour la santé de vos résultats," Canadian Journal of Remote Sensing, vol. 22, no. 2, pp. 184-189, 1996.

[54] H. Rott and G. Domik, "The SAR-580 experiment on snow and glaciers at the Austrian test site," Final Report, European SAR-580 Campaig, JRC, Ispra, Italy, 1984.

[55] N. Baghdadi, C. E. Livingstone, and M. Bernier, "Airborne Cband SAR measurements of wet snow-covered areas," IEEE Transactions on Geoscience and Remote Sensing, vol. 36, no. 6, pp. 1977-1981, 1998.

[56] V. S. Frost, J. A. Stiles, K. S. Shanmugan, and J. C. Holtzman, "A model for radar images and its application to adaptive digital filtering of multiplicative noise," IEEE Transactions on Pattern Analysis and Machine Intelligence, vol. 4, no. 2, pp. 157$165,1982$.

[57] F. T. Ulaby, P. P. Batlivala, and M. C. Dobson, "Microwave backscatter dependence on surface roughness, soil moisture and soil texture-part I. Bare soil," IEEE Transactionon Geoscience Electroncs, vol. 16, pp. 286-295, 1978.

[58] R. D. Martin Jr., A. Ghanssem, and E. T. Kanemasu, "C-band scatterometer measurements of a tall grass prairie," Remote Sensing of Environment, vol. 29, no. 3, pp. 281-292, 1989.

[59] L. P. Simmonds and E. J. Burke, "Estimating near-surface soil water content from passive microwave remote sensing-an application of MICRO-SWEAT," Hydrological Sciences Journal, vol. 43, no. 4, pp. 521-534, 1998.

[60] M. Bernier, J. P. Fortin, Y. Gautier, R. Gautier, R. Royand, and P. Vincent, "Determination of snow water equivalent using radarsat data in eastern Canada," Hydrological Processes, vol. 13, no. 18, pp. 3041-3051, 1999.

[61] K. M. Hinkel and S. I. Outcalt, "Identification of heat-transfer processes during soil cooling, freezing, and thawing in central Alaska," Permafrost and Periglacial Processes, vol. 5, no. 4, pp. 217-235, 1994.

[62] R. Paquin, "Survie à l'hiver des plantes fourragères et des céréales sous les climats nordiques, en particulier au Québec: progrès et prospectives," Phytoprotection, vol. 66, pp. 105-139, 1985.

[63] T. Zhang, T. E. Osterkamp, and K. Stamnes, "Influence of the depth hoar layer of the seasonal snow cover on the ground thermal regime," Water Resources Research, vol. 32, no. 7, pp. 2075-2086, 1996.
[64] Y. M. M. Bishop, S. E. Fienberg, and P. W. Holland, Discrete Multivariate Analysis: Theory and Practice, MIT Press, Cambridge, UK, 1975.

[65] R. A. Montserud and R. Leamans, "Comparing global vegetation maps with the Kappa statistic," Ecological Modelling, vol. 62, no. 4, pp. 275-293, 1992. 

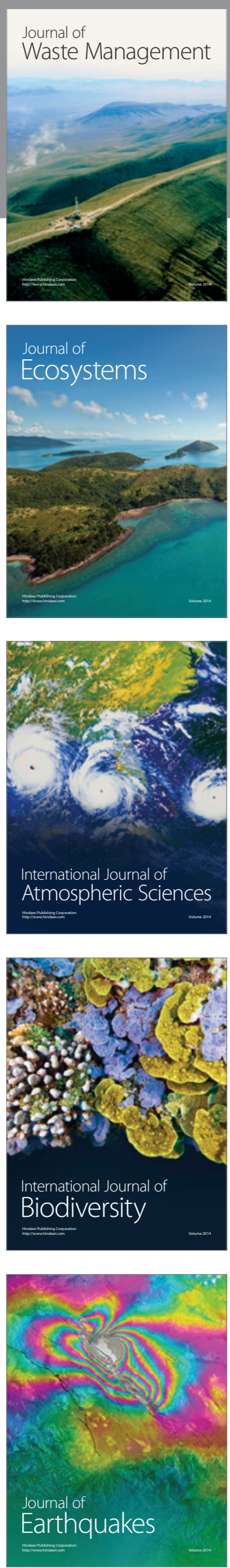
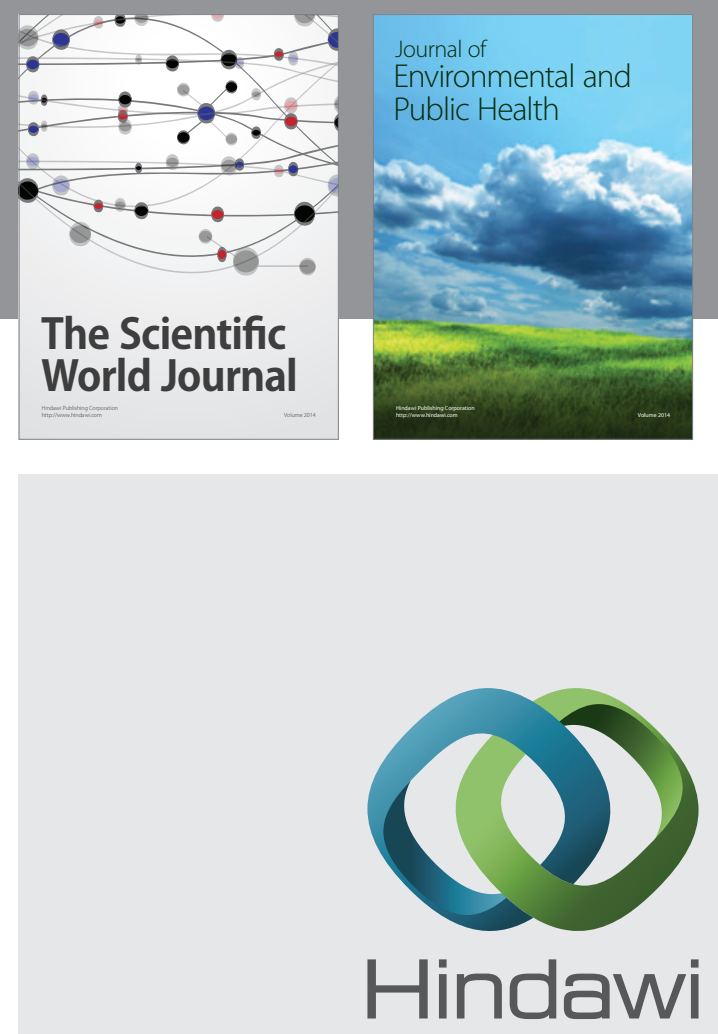

Submit your manuscripts at

http://www.hindawi.com
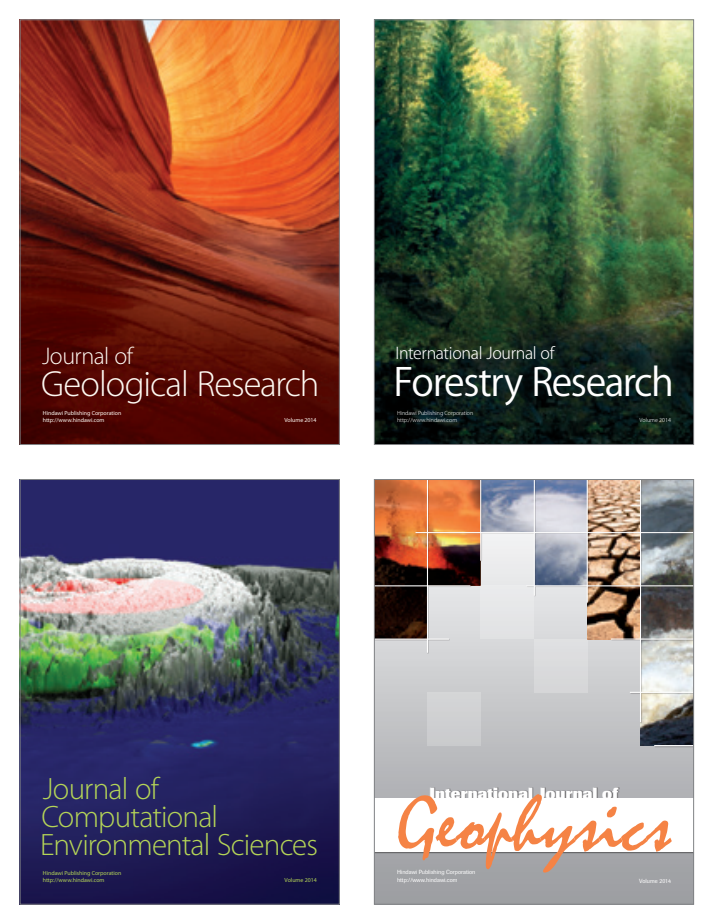
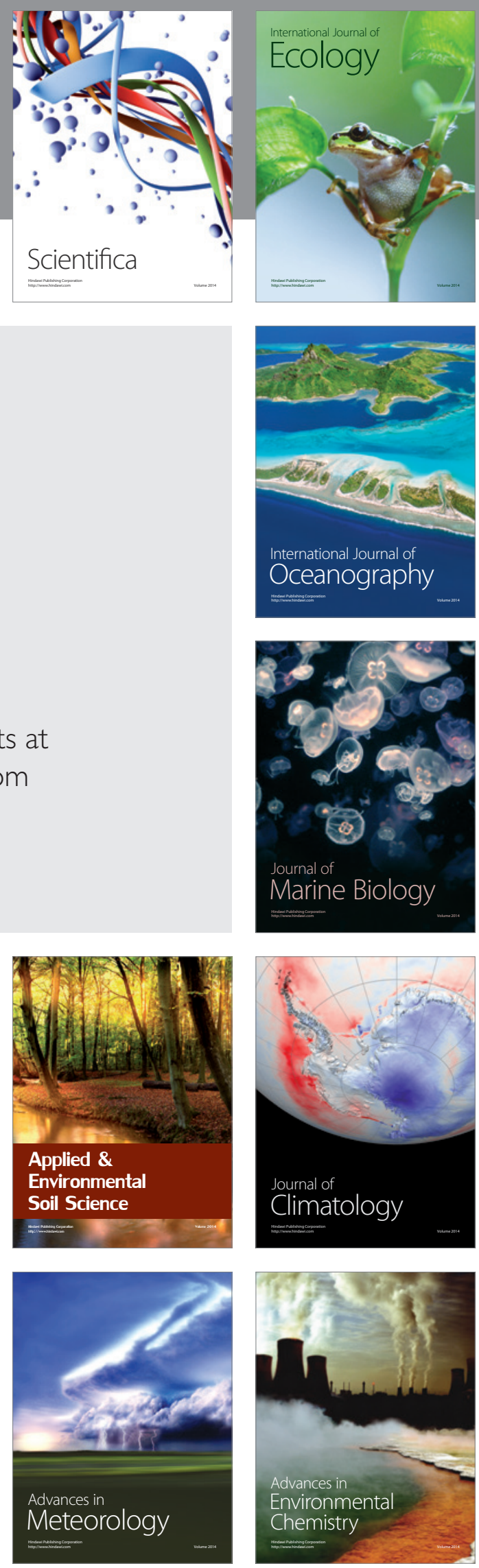